\title{
Research on Marketing Modes of New Retail Based on 4C Principles: a Case Study of UNIQLO
}

\author{
Xiaohong Tan \\ School of Foreign Languages \\ Xinhua College of Sun Yat-Sen University \\ Guangzhou, China
}

\author{
$\mathrm{Yu} \mathrm{He} *$ \\ School of Foreign Languages \\ Xinhua College of Sun Yat-Sen University \\ Guangzhou, China \\ *Corresponding Author
}

\begin{abstract}
With the increasingly prominent diversification of consumer demands, a single sale channel via either traditional retail stores or e-commerce cannot meet consumers' desires for touch and instant gratification, good shopping experience as well. Driven by new technologies, the concept of New Retail was introduced in 2016 integrating online and offline resources to accurately grasp customer needs and better serve consumers, it ultimately cushion the slowdown in the growth of Total Retail Sales of Consumer Goods. For many clothing retailers, the rapid development of online e-commerce has boosted their sales, but then has greatly impacted sales performance of their physical stores. However, the past three successive years from 2016 to 2018 have witnessed UNIQLO's great success of being clothing sales champion in TMALL. As a foreign brand, it continues to expand in China even as the clothing industry slows down year by year, with more brands closing stores sharply. Therefore, this paper attempts to analyze how UNIQLO applies the New Retail marketing modes in China to accurately meet the needs of consumers, maximizing shopping experience based on the $4 \mathrm{C}$ principles.
\end{abstract}

Keywords-New Retail; 4 C principles; marketing; UNIQLO

\section{INTRODUCTION}

In 2016, Jack Ma, chairman of Alibaba Group for the first time mentioned that New Retail came from the deep combination of online and offline logistics with the help of big data, cloud computing and other innovative technologies. Soon afterwards, Zhao Shumei [1] defines New Retail from the perspective of marketing theory as all activities that enterprises apply advanced Internet thoughts and technologies, use the latest concepts and thinking as the guidance, improve and innovate traditional retail methods, and sell goods and services to final consumers as well. Yan Zhanghua and Liu Lei [2] argue that the connotation of New Retail is to obtain comprehensive data and improve retail efficiency from the perspective of consumers experience through online and offline integration. Wang Baoyi [3] holds the opinion that New Retail is a comprehensive retail format that better meets the multi-dimensional needs of shopping, entertainment and social activities of consumers with omnichannel and pan-retail forms in the era of data-driven and the consumption upgrade.
According to the above studies, these can be seen that not a few scholars agree that New Retail is empowered by big data and new technologies with the characteristic of online and offline integration, in order to better meet the increasingly complex and diversified needs of consumers, and helps suppliers to match flexibility and enlarge scale customization, so as to realize the efficient operation of the entire industry which reshapes a "people-centric" business model.

The past three years have witnessed the application of New Retail concept into retail industries such as supermarkets, food, home furnishing, and clothing, etc. In the USA, for instance, international retail giant Amazon launches revolutionary offline physical store named "Amazon Go" with its shopping philosophy of "Just Walk Out" and "No Checkout". It perfectly integrates cloud computing and big data into the New Retail, attaches importance to customer experience, connects different shopping scenarios, and takes the lead in entering the New Retail era. In China, Alibaba's Hema Fresh which reconstructs the offline supermarket and develops different online and offline combined business modules, such as fresh food, food, take-out and supermarket. By taking advantage of cloud computing, big data, artificial intelligence, Internet of things and other advanced technologies, its online traffic and offline products will be combined to provide consumers with offline experience, online ordering, rapid delivery and the most relaxed shopping experience in the least time.

With the rapid development of e-commerce, the development situation of brick-and-mortar retail enterprises becomes grim. The wave of store closings continued in 2015 and China's traditional clothing industry was greatly affected. Statistics show that the clothing industry closed nearly 10,000 stores in 2015 [4]. However, UNIQLO has ranked the first in sales volume in TMALL double eleventh for three successive years, accounted for $25 \%$ of the Chinese clothing market in 2018 [5]. As an early pioneer of getting in touch with the concept New Retail among clothing brands, it has explored New Retail marketing modes and achieved certain results, maintaining an annual expansion rate of about 80 stores in China. Therefore, taking UNIQLO as an example to study the New Retail marketing mode conforms to the needs 
of the development of the times and has positive significance to improve the competitiveness of the clothing brand as well.

How does UNIQLO's New Retail marketing work? This paper is to analyze the performance of the marketing strategy based on the $4 \mathrm{C}$ principle, and try to explore the advanced experience and inspirations of UNIQLO's New Retail marketing modes for China's clothing brands.

\section{THE CHARACTERISTICS OF NEW RETAIL}

New Retail is a combination of e-commerce, physical retail and logistics, paying more attention to the application of cloud computing, big data and other high new technologies to improve the efficiency of sales and procurement and enhance the shopping experience. With the help of big data, offline store served as an extension of the online platform, to replenish the online platform for consumers to purchase experience. Meanwhile, online platforms bring traffic to offline stores and eliminate inventory to a great extent, reducing the inventory pressure of stores or warehouses. Wang Baoyi [3] held that New Retail possesses three characteristics as followings:

\section{A. Deepening Integration of "Online + Offline + Logistics"}

Aiming to provide comprehensive services for consumers, the integration of "online, offline and logistics" creates a full range of shopping experiences, expanding the consumer base and improving profitability. Generally speaking, in order to support offline brick-and-mortar retail, enterprises will set up online shopping platform. Nevertheless, under the New Retail mode, the offline layout of online retail enterprises is actually to combine online and offline and inventory data to create an all-channel shopping experience. When there is no inventory in the physical store, the goods can be delivered online. When there is no inventory in the physical store, the goods can also be picked up in the offline physical store. Such a logistics strategy greatly reduces the pressure on the inventory of clothing brands and also reduces the storage cost. At the same time, consumers can not only enjoy the fun of online shopping anytime and anywhere, but also get the goods quickly without waiting for logistics delivery.

\section{B. Utilizing Big Data to Optimize Retail Efficiency}

In the New Retail era, big data has become the basis of the business decisions of retail enterprises, and the reconstruction of the business model with data as the core will become the key to the transformation and upgrading. Enterprise uses advanced technology to collect the data which includes memberships, payments, inventories, service and other aspects centering on consumers and feedback the whole production so as to achieve completely inventory free sales of C2B. As for Clothing enterprises, they may make full use of the big data resources obtained by the offline stores' RFID tag, video monitoring and other technologies knowing which clothes have been touched by customers and which clothes have been put into the fitting room, etc. All customer response data can be collected and recorded, and then used to guide product planning. For consumption data accurately captures consumers' buying habits and demands, enterprises can achieve on-demand production so that effectively solve the dilemma of excess inventory. At the same time, the digitization of commodities, members and terminals will accurately guide and meet the potential demand of consumers, so as to increase consumer stickiness and expand sales profits.

\section{Creating Innovative Consumption Scenarios Based on User Experience}

The consumption-oriented nature of New Retail is highlighted and efforts are made to provide customers for efficient and satisfactory services even exceeding expectations. As online and offline boundaries are eliminated, physical stores need to be more digital and intelligent so as to make offline services more in line with consumer demands in the new retail era. By providing a relaxed and happy shopping scene, consumers can feel an emotional and warm experience, and thus generate more loyalty and dependence. Therefore, the essence of scene marketing is to let customers have emotional resonance, enhance consumer desire and expand consumption.

\section{ANALYSIS ON CURRENT SITUATION AND THE DEVELOPMENT OF UNIQLO}

With the support of new technologies such as mobile payments, big data, and Virtual Reality or Augmented Reality, and the background of slowdown in the growth of total retail sales of consumer goods, in order to stimulate the growth of retail industries, the concept of New Retail comes into being. According to qianzhan.com, in 2017 New Retail market just reached 38.94 billion yuan. By 2018, New Retail market size forecasts to be 1.8 trillion in 2022 with a compound annual growth rate of $115 \%$. Less than three years after proposing New Retail concept, retail industries such as supermarkets, food, home furnishing, and clothing are all eager to start operating New Retail business.

Founded in 1984, the brand UNIQLO is a wholly-owned subsidiary of fast retailing group (FASTRETAILING) which is Japan's largest clothing retail enterprise, established in 1963 , and it is known for providing high-quality privatelabel casual wear at low prices. At the beginning, UNIQLO also is just a tiny clothing store that merely sells suits. As time goes by, UNIQLO has become the Asia and even international famous fast fashion clothing brand, the world's fourth largest, and the first big Asian parity apparel brand.

As an early pioneer of getting in touch with the concept New Retail among clothing brands, UNIQLO has been exploring New Retail marketing modes and has achieved certain results maintaining an annual expansion rate of about 80 stores in China. 
TABLE I. Statistics About DeVelopment of UNIQLO Stores In China Mainland Until August 2018

\begin{tabular}{|l|l|l|l|l|}
\hline \multicolumn{1}{|c|}{ Stage } & \multicolumn{1}{|c|}{ Key development areas } & $\begin{array}{l}\text { Number of } \\
\text { developments }\end{array}$ & $\begin{array}{l}\text { Total number } \\
\text { of stores }\end{array}$ & \multicolumn{1}{|c|}{ P.S } \\
\hline $\begin{array}{l}\text { Initial period } \\
\text { (2002-2005) }\end{array}$ & $\begin{array}{l}\text { Shanghai, Beijing, } \\
\text { Hangzhou }\end{array}$ & 9 & $\begin{array}{l}\text { In 2005, two stores in Beijing were closed; } \\
\text { none of them were profitable. }\end{array}$ \\
\hline $\begin{array}{l}\text { Growth period } \\
(2006-2010)\end{array}$ & $\begin{array}{l}\text { East China, North China, } \\
\text { South China }\end{array}$ & 100 & 113 & $\begin{array}{l}\text { Taobao's flagship stores in 2009; the first } \\
\text { global flagship store in 2010 }\end{array}$ \\
\hline $\begin{array}{l}\text { Extension period } \\
\text { (2011-2014) }\end{array}$ & $\begin{array}{l}\text { East China, North China, } \\
\text { South China, Southwest }\end{array}$ & 222 & 335 & New global flagship store in 2013, Shanghai. \\
\hline $\begin{array}{l}\text { Maturity period } \\
(2015-2018)\end{array}$ & Second and third tier cities & 298 & 633 & The largest digital store in 2018, Shenzhen. \\
\hline
\end{tabular}

As indicated in the "Table I", UNIQLO can be divided into three stages in China market. From 2002 to 2005, it was the initial exploration stage in China market with low expansion speed for its marketing strategy was completely copied in Japan, but the effect was not good. From 2006 to 2010 , it was the growth period for UNIQLO reformed and adopted a series of measures such as supply chain integration and diversification in China at the end of 2006, especially achieving good results in 2007. Since then the brand was gradually accepted by the public as well as the expansion of stores was accelerated. Until August 2018, UNIQLO totally attained 2068 stores worldwide, including in Japan, China and South Korea, Japan on 827 to 726 in Greater China (633 in Mainland China, 28 in Hong Kong and 65 in Taiwan) maintaining an annual expansion rate over 80 stores in Greater China. Currently, UNIQLO keeps on expanding and growing in Southeast Asia, Europe and the United States (uniqlo.com).

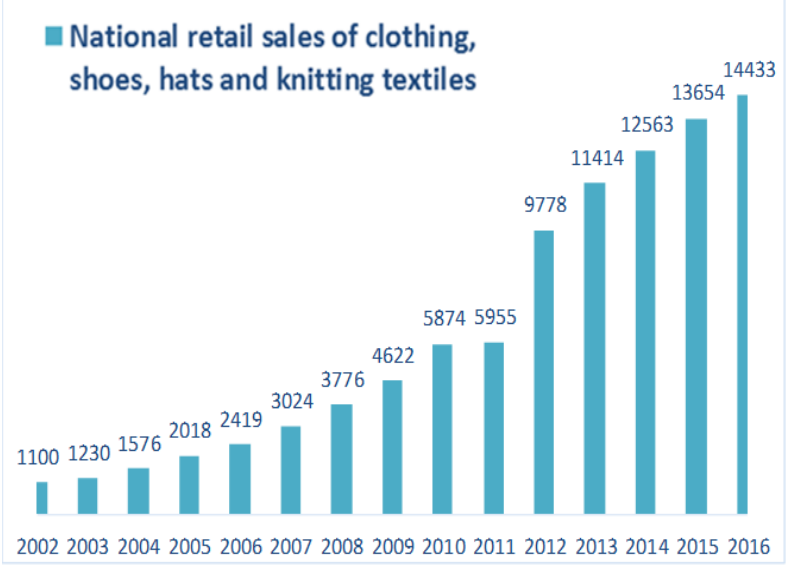

Fig. 1. National Retail Sales of Clothing \& Shoes \& Hats \& Knitting Textiles from 2002-2016.

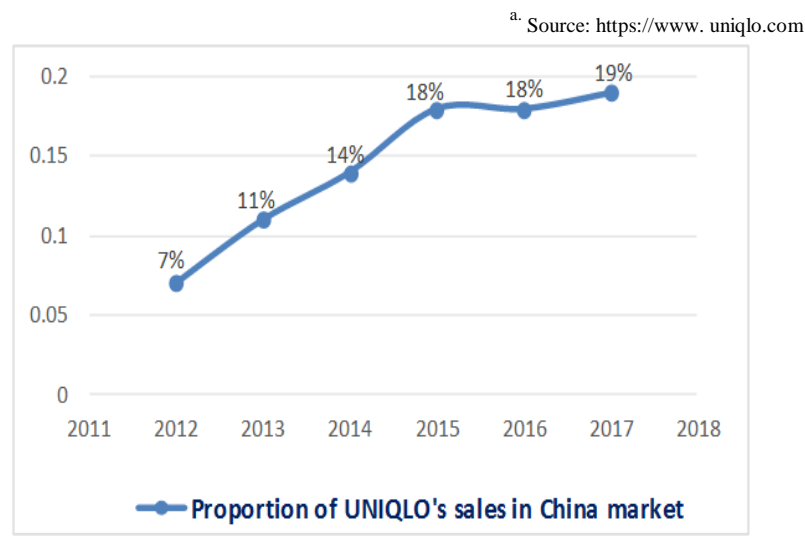

Fig. 2. The Proportion of Sales of UNIQLO's in China Market from 2011 to 2017 .

Source: 2011-2017 "Fast Retailing Annual Report"

As illustrated in "Fig. 1", the national retail sales of clothing and other products have increased year by year and the growth rate also has boosted year by year. In the past 15 years from 2002 to 2016, the growth rate of clothing retail sales has reached $1212 \%$. Bullish on the growth potential of China market, in September 2002, UNIQLO decided to enter China market. At the very start, UNIQLO served as a foreign brand, has struggled in China and its market share even has been divided by brand BALENO and GIORDANO. After years of development, as illustrated in "Fig. 2", UNIQLO's market share has been increasing from $7 \%$ in 2012 to $19 \%$ in 2017 , with an average annual growth rate of $2.4 \%$.

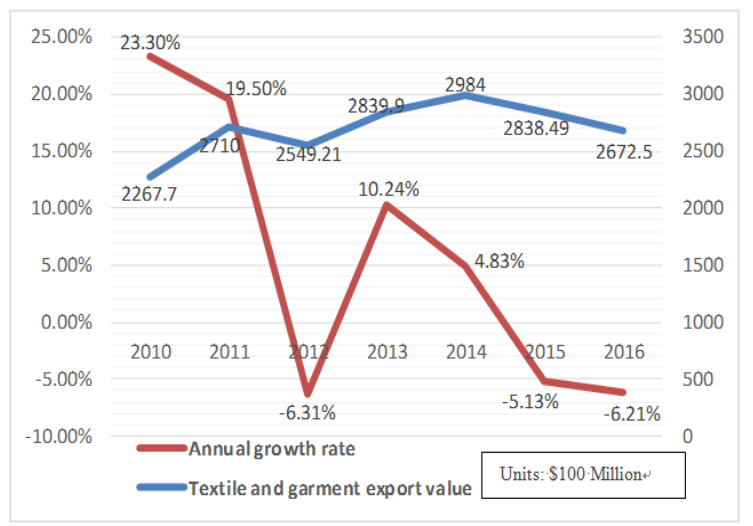

Fig. 3. Statistics of China's Textile and Garment Exports from 2010 to 2016. 
As shown in "Fig. 3", it's easily know that the annual growth of China's textile and garment exports significantly declined from 2010 to 2012, and even reached a bottom of negative $6.31 \%$. Under the context of this situation, UNIQLO also experienced fierce competitions with other fast fashion brands such as Zara and H\&M, and risky threats from ultra-fashion brands which only relied on online stores to sell with faster clothing delivery speed and lower operating costs without burden of physical stores. Therefore, UNIQLO realized that core competitiveness such as fast and fashion was not enough so that it turned to a lifestyle concept based on technology. That's why UNIQLO changed its brand slogan from "Made For All" to "LifeWear" in 2013, and before the New Retail concept was put forward, took action to combine elements of offline and online retail, making them an integral whole, achieving a multi-channel layout of "offline store + official website + TMALL flagship store + mobile app", which its e-commerce, physical retail, and logistics were bridging, improving the efficiency of selling and buying as well as the shopping experience.

In 2016, in order to respond quickly to customer demands, a project called Ariake Project was launched by UNIQLO. It underlines on the integration of offline stores and online stores, big data and new technologies to analyze or capture consumers' needs and digitizes the supply chain so as to lower the cost. Thanks to the bold change, it has benefited UNIQLO's business, which created revenue of 1.87 trillion yen, up $4.2 \%$ from a year earlier (2017 Fast Retailing Annual Report). In 2018, UNIQLO has accounted for $25 \%$ of the Chinese market, making China the world's second largest market for UNIQLO brands (2018 Fast Retailing Annual Report).

Thanks to implement New Retail marketing, UNIQLO has grown at an astounding pace. According to the 2018 financial year's performance report released by UNIQLO parent company Fast Retailing group in October 2018, the overall sales of the Fast Retailing Group were 1.76 trillion yen (13.90 billion RMB), an increase of $14.4 \%$ year-on-year. Japanese market accounted for $48.9 \%$ while the overseas market accounted for $51.1 \%$. China is a major overseas market, accounting for $25 \%$ of the market share. China also achieved double-digit growth in online sales, raising the proportion of online sales to $15 \%$ of total sales. By 2020, it plans to increase to 1,000 stores (2018 Fast Retailing Annual Report). In respect to online sales, according to the chinairn.com, UNIQLO has ranked first in the sales of clothing brands in TMALL double 11 for three successive years. In 2018, its sales of TMALL flagship store in double 11 reach 100 million yuan in only 35 seconds, breaking its sales record: from the top one seller on TMALL to the first brand reached 10 million Yuan [6].

\section{UNIQLO'S MARKETING MODES OF NEW RETAIL BASED ON 4C PRINCIPLES}

In 1990, a marketing expert in the United States, Robert F. Lauterborn [7] put forward the famous 4C Principles based on consumer demands, namely, Consumer, Cost, Convenience and Communication. In comparison with the traditional 4Ps theory, 4C principles underline customers' feelings, emphasize customer satisfaction as the goal, and attach importance to the communication and exchange with customers. Under the background of New Retail, more and more enterprises will guide consumers to like the process of purchasing and be willing to buy products by focusing on how to create convenience and comfort to them.

\section{A. Seizing Consumer Demands and Desires Based on Online and Offline Integration}

4C attaches great importance to consumers' need and want. Final success can be achieved only with deep understandings of consumer's real demand and desire. Therefore, under the background of New Retail, enterprises need to focus on customers not only in aspects of products, but also service and offline shopping experience as well. UNIQLO in this respect understands and catches user's wants by various means.

On the eve of the 2016 Double 11, according to a survey named "2016 Double 11 Consumer Expectations" conducted by UNIQLO and Isobar China Group. Nearly 40,000 consumers voted during the period from October 21 st to October 28th. It shows that 99 percent of consumers hope that online and offline shopping's price are the same, and $56 \%$ of consumers expect to speed up the delivery service during the double 11 . With regard to the delivery speed, 81 percent of consumers want to pick up the goods directly at the nearest store.

In order to facilitate the timely delivery of items that customers needed most, UNIQLO has implemented delivery strategies by cooperating with TMALL, such as "same price online \& offline" and "online order offline pickup". It solved the problem of insufficient online inventory and let customers receive their goods as soon as possible. According to UNIQLO statistics, due to these new strategies, in 2017 double 11, UNIQLO generated five times sales as it did a year ago. And the order pickup service has driven over $10 \%$ to $15 \%$ randomly additional consumption when customers come to stores picking up the order [6].

According to a report "New Retail during 2018 Chinese New Year" released by UNIQLO and iResearch, it displays that $56 \%$ people have luggage issues during Chinese New Year and they hope that travel with less stuff and $68 \%$ consumers will use the New Retail and offline service to buy gifts for their families even though they might not come back home. Also 59 percent of customers are bothered by the delay of package delivery during Chinese New Year while 71 percent of people hope to get better customer service than in-store services, such as exchange and return. What's more, $78 \%$ of customers will buy goods for Chinese New Year and clothing will be increasingly the first option.

Based on these insights, UNIQLO has provided consumers solutions to solve the problems like suspense of delivery service or carrying too many pieces of baggage on Chinese New Year as followings: UNIQLO offers customers a service of ordering at location $\mathrm{A}$ and picking up from location B from 2018 Chinese New Year now on. To put it in another way, after customers place an order at UNIQLO's online store, they or their friends or families can pick it up at 
a nearby UNIQLO offline store. Besides, free tailoring and changing sizes will also be available during the Chinese New Year.

\section{B. Economical Cost Based on Big Data and Intelligence}

The second $\mathrm{C}$ to be considered in $4 \mathrm{C}$ principles is the customer cost. For consumers in the New Retail market, customer cost does not only limit to the product price itself, but also includes the time and energy during buying. Therefore, customer cost should consist of the monetary cost, time cost, mental cost and physical cost [7]. In order to maximize the customer's satisfaction, UNIQLO has taken adequate consideration to the "total customer cost" that the customers would like to pay during preparation of marketing plans.

First of all, in terms of monetary cost, UNIQLO's product planning, manufacturing and distribution capabilities are all in-house, which means that it is able to stay close to customer needs based on what customers are buying at stores, allowing them to save costs on overproduction or unnecessary overheads. Stocks can be upgraded within a matter of weeks or replenished within a matter of days. By focusing on core products in a limited range of fabrics, UNIQLO is able to consolidate its fabric buys into huge orders that give it greater negotiation power against suppliers which translates into cheaper prices with the main range from 39 to $499 \mathrm{RMB}$ for its customers. As for the discounts that customers care most about, in order to maintain the optimum level of store inventory, UNIQLO will adjust the timing of any price changes and offer its products at discounted rates. Specifically, most products will have a price reduction of about 3 times per year, and finally they will be $50 \%$ off or even $60 \%$ off. In short, Flexible price changes and discounts have resulted in consumers' satisfaction enhancing the repurchase rate and an increase in UNIQLO sales figures leading to greater revenues and highprofit margins as well.

Besides, in respect to the mental and time costs, consumers often spend a lot of time and effort to access various digital channels like website or APP to collect complete product information. Therefore, enterprise should recapitalize resources to update digital channel for the convenience of receiving information as much as possible. In May 2018, artificial intelligence would be tapped to tackle questions. UNIQLO launched an AI Personal Assistant named UNIQLOIQ which is used by its customer via its own app and WeChat Public Account. This automated chatbot, UNIQLOIQ pumps out search results as quickly as the customer can type them into the search bar and helps the users to narrow down their searches by specifying usergenerated filters of what they're looking for, such as gender, clothing type, or color. Thanks to automated chatbot, it creates a better consumer shopping experience and finally drive over $10 \%$ consumption rate [8].

At last, in terms of physical cost, physical cost saving should be one of the advantages of New Retail marketing. With the support of smart logistics and new technology, consumers can enjoy considerate home delivery service.
Meanwhile, customers are allowed to buy the chosen product within the app and direct them to the nearest store for a try on.

\section{Convenience to Purchase Based on Visual Reality and Artificial Intelligence}

The third $\mathrm{C}$ of the 4C theory highlights consumers to buy their interested goods handily [7]. So enterprises should attach importance to providing consumers with the greatest convenience in purchase no matter online or offline under the New Retail.

As for convenience in online shopping, in October 2018 , UNIQLO launched a program named "one-click shopping in the flagship store" which allows consumers to quickly find the entrance to the flagship store for shopping based on their buying habits. Consumers enable to enter from the official website, official APP, WeChat applet and offline store by code scanning. No matter when and where, consumers can enter the applet or APP to complete the one-button shopping. At the same time, official APP, WeChat applet has been designed and adjusted accordingly to convenience in purchase, including optimizing the sharing function for users to forward WeChat moment conveniently, Adding goodschecking function providing detailed product information, and strengthen 4D fitting function to display the wearing effect more directly.

Thanks to the convenience of social word of mouth recommendation, multiple platform entrance and one-click order service, in 2018 double 11 , it took 35 seconds for UNIQLO's TMALL flagship store to break 100 million yuan in sales, compared with one minute, two minutes and 53 seconds in 2017 and 2016 [6].

In regard to convenience in offline shopping, with the purpose to make consumers easier to find what they want, an electronic smart screen named" Intelligent U Guide" which is exclusively displayed in Shenzhen Digital Store in 2018 and soon will be promoted to stores across the country, gains more attention for it can be played as a digital fashion coordinator and digital sales assistant, and the outfit style is performed in 4D when consumers press a button on digital fashion coordinator. Digital sales assistant will offer guidance when consumers shop. What most impressive services that "Intelligent U Guide" provides are called "offline order, online delivery". It is well to be reminded that the smart assistant could help drive traffic to TMALL online stores from physical stores. Thus consumers could directly choose clothing and put an order on the screen, and UNIQLO would send the product delivery as soon as possible. It relieves the burden of carrying shopping bags and also saves time of waiting in the line to check the bill.

At present, more functions are still being developed, including the ability to place an order directly in stores on electronic screens. This can be seen as an advanced version of the electronic screens named "smart buyer" whose interactive efficiency was more than four times that of traditional media, enhancing the shopping conversion rate of $15 \%$ in stores, launched in 2017 [9]. 


\section{Effective Communication with Customers Based on Smart Store and Big Data}

The fourth $\mathrm{C}$ in $4 \mathrm{C}$ principles is communication. The constant communication is required with the consumers so as to cultivate the loyal consumers. The new retail marketing based on $4 \mathrm{C}$ principles aims to underline marketing activities that are not only an unilateral promotion, but also to communicate with enterprises and users, so that enterprises timely obtain information and feedback from users and big data analyzing user preferences and habits as well, and improve products, services, shopping experiences adjusting strategies.

Before the era of Internet comes rapidly, UNIQLO traditionally relied on leaflets, newspapers, TV commercials as its primary ways of advertising. Nowadays, it takes advantage of massive methods to communicate with consumers conveying its brand concept and ideals, including its unique in-store environment, celebrity endorsements, digital marketing, and collaborations with designers and brand campaigns as well. However, among these methods of communication, unique in-store environment is what UNIQLO values most. Through its wide aisles, bright lights, neatly stacked shelves, beautifully presented displays many digital screens in-store explaining the practical benefits of its fabrics and apparels and interacting with consumers entertainingly creating a comfortable and welcoming shopping experience, it contributes greatly to effective communication of its brand style and cultivate loyal customers. "What most effective communication method for UNIQLO is in-store environment under the New Retail", quoted from Jalin $\mathrm{Wu}$, the CMO of UNIQLO. She believed that excellent product and service experience actually stimulate their buying desire and enlarge the sale market instead of brands' marketing campaigns.

Even so, UNIQLO still keeps continuous communication with customers from the perspective of adopting aggressive marketing policies. In order to increase its brand awareness in both its home country and in the overseas market, it utilizes increasingly digital tools to communicate directly with customers and quickly transform their desires into actual products. Each year, UNIQLO conducts promotional campaigns for core products such as HEATTECH, Ultra Light Down jackets, and AIRism During the campaigns, which advertises the products' unique qualities and noteworthy features and convey its brand philosophy as well as guide consumers to think differently about clothing on TV and in other media.

For the purpose of adjusting strategies timely and fulfilling individual needs, UNIQLO attaches great importance to customers' feedback and their shopping records. Indeed, it has established an insight team to conduct UNIQLO annual market research at least once a year and improve core ranges by analyzing enormous volumes of requests and comments from online customers. Also, for the sake of knowing consumer behavior, such as when consumers pick up and return items to shelves, and when and where products are sold. In 2017, UNIQLO stores introduced RFID (radio frequency identification) tag which can collect timely accurate and specific information such as volume, type and color. Compared with manual bar codes, RFID tags can automatically read information and save more labor and inventory costs so as to ensure that the company can rapidly improve the output of hot selling products. At present there are many clothing brands applying RFID technology in the entity shop, such as Decathlon, ZARA and INMAN According to Jean-Marc Lieby, head of decathlon's RFID programme, he said that the technology not only increased sales by $5 \%$ but also reduced losses by $9 \%$ [10].

\section{CONCLUSION}

UNIQLO's marketing modes of New Retail accurately meet the needs of Chinese consumers, maximizing shopping experience based on the $4 \mathrm{C}$ principles. The author believes that UNIQLO deepens integration of online and offline logistics to satisfy customers' desire of shopping convenience, and makes full use of big data to achieve precision marketing and price customization to effectively deliver brand ideas and achieve effective communication. In addition, new technologies such as the introduction of sensors and the Internet of things are applied to accurately perceive the movement trajectory and shopping behaviors of potential customers once upon their arrival at the store to create corresponding data and help adjust the direction of production, optimizing the store display and operation to better improve the customer experience. Thus it throws light on its Chinese clothing peers' development.

\section{ACKNOWLEDGMENT}

Guandong Province Project Study on the Mode of CBET Talent Cultivation based on school-enterprise cooperation for Business English Undergraduate Program in the Applicationoriented Colleges under "The Belt and Road Initiative" (Grant Number : 2017GXJK231).

The Department of Education of Guangdong Province and Xinhua College of Sun Yat-sen University to the Xinhua SYSU Nuote Practice Base Project (Grant Number: 2015D002).

\section{REFERENCES}

[1] Zhao Shumei \& Xu Xiaohong. The Meaning, Pattern and Development Path of "New Retail" [J]. China Business and Market, 2017 (05): 12-20

[2] Yan Zhanghua \& Liu Lei. The Concept, Research Framework and Trend of "New Retail" [J]. China Business and Market, 2017(10): 1219.

[3] Wang Baoyi. Research on the Essence, Causes and Practice Trends of "New Retail" [J]. China Business and Market, 2017 (07): 3-11.

[4] Clothing Industry Has Ushered in the trend of closing stores, and why is it getting harder to open a clothing store. Sohu.com. 15 Dec. 2017. $\begin{array}{lllll}\text { Accessed } & \text { on } & 2 & \text { Feb. } & 2019 .\end{array}$ <http://www.sohu.com/a/210862551_807893>

[5] China Is the Second-largest Market for UNIQLO Accounted for 25\%. Winshang.com. 16 Feb. 2019. Accessed on 20 Feb. 2019. <http://news.winshang.com/html/065/3530.html>

[6] Wang Yu. The Textile Clothing Companies behind UNIQLO, Sales Leader on 2018 Tmall Double 11. Chinairn.com. 17 Dec. 2018. 

Accessed on 2
Feb.
2019.

<http://www.chinairn.com/hyzx/20181217/110149494.shtml>

[7] Lauterborn, Robert. New Marketing Litany: Four Ps Passé: C-Words Take Over [J]. Advertising Age, 1990 (03): 13-14.

[8] UNIQLO Launched an AI Personal Assistant Named UNIQLOIQ Ebrun.com. 9 May. 2018. Accessed on 10 Feb. 2019. <http://www.ebrun.com/20180509/276620.shtml>

[9] The Stores Conversion Rate Increased $15 \%$ and the Media Interaction Effect Increased Five Times: How UINQLO Plays New Retail With an LED Screen. Sohu.com. 21 July. 2017. Accessed on 3 Feb. 2019. <https://www.sohu.com/a/158809244_617271>

[10] Lin Junqi. Decathlon's RFID Project Has Achieved Remarkable Results: Embisphere provides RFID Solutions for Decathlon. Rfidworld.com. 10 Oct. 2015. Accessed on 2 Feb. 2019. <http://news.rfidworld.com.cn/2015_12/3c88cb0695001f30.html> 